\title{
Study on the Factors Affecting Computer Aided English Teaching
}

\author{
Huahong Rao ${ }^{1}$ \\ ${ }^{1}$ Tongren University, Tongren, Guizhou, 554300 \\ 346591653@163.com
}

KEYWORDS: Computer Aided English Teaching; Factors; Campus Internet

\begin{abstract}
Shortly after the emergence of multimedia, computer is quickly used into the field of education, computer-assisted instruction to bring a revolution. With the advance of information technology to improve education, computers, and other hardware facilities of the campus network, computer technology in secondary English teaching increasingly widespread, and have played an increasingly important role. In this paper, the impact of computer-aided English teaching and many other factors, the use of analytic hierarchy process to analyze their characteristics and their role, to arrive at the impact of computer-aided English Teaching students the most important factor is the conclusion of the teaching methods of learning and teachers and the establishment of a regression model. Papers presented AHP, because of its simple, effective and science has a certain value in practice.
\end{abstract}

\section{Introduction}

With the continuous development of information technology, computer science and technology as the richest characteristic of modern teaching tools, more and more applied to all aspects of education. CAI (Computer Assistant Instruction Computer Assisted Instruction) a typical application in teaching is increasingly a profound impact and change our teaching activities as a computer, so that our teaching methods, teaching methods, education ideas and management models, etc., It has undergone tremendous changes. So how to make full use of computers and multimedia educational software, explore new teaching model has increasingly become a hot research.

English teaching, teaching for the students' language abilities, which requires students to have a good language environment, and the computer was introduced into the teaching among its main role is to provide multimedia language environment for students to simulate some of the reality of the scene, to create a more user-friendly space for dialogue and atmosphere, not only can image all-round student of each sensory stimulation through sound, fully mobilize the enthusiasm of the students, but also to better enable students to exercise their English skills in different scenarios .

\section{Situation of College English Teaching}

Currently specializing in computer-aided Teaching in College English Listening and Speaking Course in research and application has matured. Computer-assisted instruction, English has become the most important lesson I heard a professional teaching methods, however, raise one hand does not make the overall development of students, we must also improve students' reading, writing, translation ability. As can best reflect a person's level of English writing English, English learners is 
still the most troublesome problem. A large number of English learners faced with a problem: how to write English composition.

At present, China teaching high school English for English composition neglect leads to students after entering the university, still do not pay attention to English composition. English writing is not interested in students a common problem. Face with essay topics and nothing to say, casually Minato word, a student common practice. Teachers are in the marking composition, to focus on the grammar, syntax and so on, ignoring the students' writing skills and writing methods.

Based on the current situation of English professional writing courses, and computer-aided Teaching of English Writing research, we have introduced computer-assisted instruction teaching writing courses, conducted a useful exploration.

\section{Effect of Computer Assisted Instruction on English Teaching}

Traditional English listening teaching, are teachers use classroom time, on the podium with a tape recorder to play, let the students listening training and learning, but the traditional way of training students tend to make only sounds to produce a dry and dull feeling, and listening to the computer applications which can greatly improve this situation, first of all, we can let students have more time and opportunity to watch some movies no Chinese subtitles in recess, so that students through the grasp the plot, as much as possible to understand the meaning of English, so that greatly improved the students' English listening ability, and secondly, we also regularly organize students to participate in some activities in English or English listening to and watching some of the television programs, Listening host culture by listening to English spoken, to better exercise and improve their English skills, affecting two computer aided teaching spoken English language ability of a person to a large extent reflected in the spoken language skills, thus cultivating and improving students' English speaking ability is particularly important, and computer-assisted instruction for English teaching of great help, English is the language environment and focus on scenarios, therefore, the aid and the use of computer-assisted instruction can be more vividly English The spoken language training to provide a good condition, the creation of one kind of lively, open and free scenarios, help students better integrate into, so that students willing to accept the knowledge, the initiative to use English in order to continuously improve their English speaking skills, English teaching The main purpose is to train students to form this most basic of English listening and speaking ability, students in the use of computer software to learn English at the same time, not only to get richer classroom knowledge through channels, but also by listening, Say, Read, Write, Sing, Look multidimensional study of three-dimensional space, of course a more detailed understanding of knowledge, not only deepened the understanding of English vocabulary, grammar learning and memory, but also be able to apply their knowledge to achieve results.

\section{Computer Aided English Teaching Practice}

Computer aided teaching can improve students' enthusiasm and initiative. So that students really want to write, willing to write. Interest determines the efficiency of the brain learner. Traditional teaching methods ignore the interests of the students training, students in a state of passive acceptance, thinking only of their imprisoned teachers thinking mode. This chalk and talk approach will not only harm students' confidence and determination, more likely to lead him to produce resentment in English. If we can take advantage of a rich network of resources, combined with the theme of each section of the course, appropriate for students to show pictures, sound and movie clips and animation, etc., not only can fully mobilize the students' senses, to stimulate student 
interest in multimedia and classes, and more can provide rice can cook it for them and help them explore new ideas. For example, on an exercise class, we write an article about the love of. When I put this abstract theme tell students when exposed some students confused expression, I do not know how to talk. I then put three pictures (of love between men and women, respectively, friendship affection between father and daughter and between friends) respectively show it to everyone, and broadcast a video data. It gives tips and questions and discussions with everyone, teachers and students to discuss the textbook prompt questions. The classroom, the students took the floor to express their views. After the discussion, the majority of students have to write a well-structured, clear thinking, sincere feelings of the article.

Some simple exercises in a grade, such as: watching movies writing stories for the film fragment design dialogue, Figure Writing, Acronym Liwen, design different endings for the story and so on. Computer Network shows vivid, funny pictures, video clips or image information, etc., entertaining, training students to achieve happiness. Facing TEM4 according to the practical needs of English Sophomores, in accordance with the requirements of majors targeted training syllabus, write argumentative general within the specified time. In this initial year, it will be based on their past experience and practical teaching experience pro forma, second sentence to teach students to write argumentative approach. So that students feel the written arguments to be easy to eliminate students' fear of argumentative. In the teaching of these twelve words, they often used to make vivid PPT slides, vividly demonstrate that these 12 words of the order and distribution patterns, and with every word corresponding exercises appear in the proper position. After completion of adding structure to teach there to fill sentences, outlines, different forms of supplementary discussion paper and other exercises. After students finish the job, in the form of $\mathrm{E}$-mail sent back as soon as teachers, so teachers to students to grasp the situation.

Using teaching methods and longitudinal horizontal contrast, for students of the same subject in different jobs in the same screen display and allow students to horizontal comparison, to discuss the advantages and disadvantages of each article and how to take excellent inferior. Or write to the same students several times on the same issue revised longitudinal comparison. Different ways, not only to enable students to deepen the impression, to avoid repeating mistakes, make them more aware of their progressing, they learn of confidence. And lay a good foundation for the third and fourth grade senior class, as well as pro forma eight professional writing. In constant practice, students of grammar level have also been greatly improved. Outline of the third and fourth grade students of the requirements is to write coursework, reading reports and thesis. At the time, students need access to large amounts of data. In this case, the computer and the Internet are to provide students with a great convenience.

Traditional teaching model and one of the major differences between computer-assisted language teaching is to transfer control of learning from the classroom to the student body, this distinction applies equally to teaching classes. In traditional teaching, teachers dominate the classroom, which is conducive to teachers teaching process monitoring progress of the course teachers will also be adjusted according to the students of the course reflect the situation. But the drawbacks are often teachers in order to complete the course schedule will be as much talked about much content within a limited time, ignoring the students' ability to accept questions and after-school links, over time, would seriously dampen the enthusiasm of students. In terms of computer aided teaching counseling students there incomparable superiority. First, computer-aided teaching system was an assistant tutor a patient. It can help us to establish a network interactive learning environment, teaching activities have been effectively extended. Namely: By establishing the online classroom so that students in extracurricular can submit jobs to the teacher answering questions at any time; you 
can also keep the interactive, online discussions with other students, sharing of resources. Secondly, computer-assisted teaching system is a knowledgeable scholar, to make students more personalized. Multimedia network can provide a wealth of different students more learning resources, but also the abstract into concrete propositions essay sound, image data, so easier and fun. Each student can also choose different resources according to their own problems and make their writing more vivid and complete. This part of the information becomes a supplement to teachers teaching.

\section{Conclusion}

Teaching students' enthusiasm, learning, student teaching mode adaptation, the teacher's impact on the larger computer-aided English teaching effectiveness, including student learning and teachers teaching methods of computer-aided English Teaching greatest impact, adjusting the way students learn and teachers can better improve the teaching methods of computer-aided English teaching effect, which coincide with the actual situation, indicating that the established hierarchy model is reasonable.

\section{REFERENCE:}

[1] Chou, S. \& Li C. Learning Effectiveness in A Web -Based Virtual Learning Environment A Learner Control Perspective [J] .Journal of Computer Assisted Learning, 25 (21), 65 -76.

[2] Shi Xiaoling. Multimedia Computer Aided Teaching English Professional Writing [J]. Anhui University of Technology, 26 (6): 38-39.

[3] Chen Kaishun. English Writing Volume [M]. Beijing, China Aerospace Press,

[4] Jin Xia. Inter Language Pragmatic Other Computer Aided English Teaching Mode and Traditional English Teaching Mode [J]. China University Teaching, 27 (9): 77-81. 